\title{
Five breeding attempts of male Common Kingfisher (Alcedo atthis) during the season consisted of pairing with two females
}

\author{
Pät' hniezdení samca rybárika riečneho (Alcedo atthis) za sezónu \\ pozostávalo z párenia s dvomi samicami
}

\section{Lucia Rubáčová*, Mária MeuIŠKová \& Monika CePKová}

\begin{abstract}
Department of Zoology, Faculty of Natural Sciences Comenius University, Bratislava, Ilkovičova 6, Mlynská Dolina, 84215 Bratislava 4, Slovakia; *e-mail: lucia.turcokova@uniba.sk
\end{abstract}

\begin{abstract}
In 2018, the unique breeding effort of Common Kingfisher was documented in the Danube River system, southwestern Slovakia. Preliminary observations indicated that one breeding pair managed to breed five times of which three attempts were successful. The aim of the present work was to determine whether the observed breeding pair exhibiting remarkable reproductive parameters did not undergo extra-pair interactions or partner exchange during a long breeding season using molecular techniques. Our results show, that male bred not with one, but with two females in sequence during the season. Male found a new mate during the incubation of the third brood. Due to the relatively short distance between nesting burrows and raising many offspring from both broods, we assume that the possibility of simultaneous bigamy is relatively low. Since the females very rarely leave males during breeding, we suggest that exchange of the female partner was due to a loss of the partner rather than a consequence of an abandonment by the female.
\end{abstract}

Key words: Common Kingfisher, multiple broods, partner exchange, polygamy

Based on the amount of behavioral work, monogamy with a strong social bond between the partners and a high level of parental care has long been considered the most common bird breeding system (Lack 1968). By using molecular genetic techniques, it has been shown that only about $14 \%$ of species are truly monogamous. Species breeding once a year exhibit often mixed paternity (Griffith et al. 2002, Westneat and Stewart 2003). Species laying multiple broods can form pair bonds for the entire breeding season (Haftorn 1978, Wallander and Andersson 2003, Stępniewski \& Halupka 2018) or switch the partners between breeding attempts (Emlen \& Oring 1977, Warriner et al. 1986, Pogány et al. 2008, Jamieson 2011).

We study breeding strategy in the Common Kingfisher (Alcedo atthis), which is considered to be socially monogamous within the season, rarely between seasons. Social polygyny or polyandry is a minor strategy, but it occurs occasionally in the population (Cramp 1992, Čech 2006, 2007, 2009, 2017, Libois 2018). No one has genetically confirmed it yet. Kingfishers breed from March to September and lay multiple broods (up to four), which usually overlap (Morgan \& Glue 1977; Cramp 1992; Novotný 1994, Woodall 2001, Čech 2006, 2010, Turčoková et al. 2016, Rubáčová et al. 2020). During the overlapping, the female leaves the young at an early age and establishes another clutch, while the male remains and takes care of the offspring, but often the female helps (Cramp 1992, Čech 2006).

In 2018, one of the longest breeding seasons of the Common Kingfisher in Central Europe 
was documented in the Danube River system. On the basis of the identification of individuals at the beginning of the season and their subsequent observation, it was assumed that one breeding pair managed to breed five times. The first two breeding attempts were unsuccessful and in the remaining three attempts parents managed to successfully raise a total of 19 young (Rubáčová \& Melišková 2020).

The aim of this work was to determine whether the observed breeding pair exhibiting potentially five breeding attempts did not undergo extra-pair interactions or partner exchange during a long breeding season using molecular techniques.

From March to September in 2018, the breeding of a kingfisher pair was checked at the locality of Fodráska (southwestern Slovakia). The breeding burrows were located in the banks of artificially created water channel connecting the blind protrusions of the Baka's branch of Danube River (47 52 ' $20.40^{\prime \prime N}$, $\left.17^{\circ} 31^{\prime} 13.01^{\prime \prime} \mathrm{E}\right)$. The distance between burrows was 170 meters. Adults were mist-netted in the vicinity of their nesting burrow. Offspring were gently extracted from the nesting chamber at the age of at least 14 days using a bent iron wire. Parents and their offspring were ringed and blood sampled before release. DNA for parentage assignation was extracted by extraction kits (E.Z.N.A. ${ }^{\circledR}$ Tissue DNA Kit). Forward primers were fluorescently labelled, and multiplex PCR kit (QIAGEN Multiplex PCR Plus kit) was used to amplify four microsatellite loci. PCR amplifications were performed in $10 \mu \mathrm{l}$ final volume, containing $1 \mu$ l of DNA, $0.1 \mu$ of primer amplifying locus AACC-106, $0.3 \mu$ of primer amplifying locus Be 2.46, $0.2 \mu$ l of primer amplifying locus BB 111, 0.2 of $\mu 1$ primer amplifying locus CAM 17, $5 \mu \mathrm{l}$ of Master Mix, $1 \mu \mathrm{l}$ Q solution a $2.2 \mu \mathrm{l}$ of nuclease free water. Fragmentary analysis was carried out commercially in the Comenius University Science Park (Bratislava, Slovakia). Results of fragmented analyses were visualised by software Gene Marker. Alleles of putative parents were compared to those of nestlings to determine if or not they were offspring within the pair. Nestlings failed to be considered as within-pair if their alleles mismatched with those of their parent at least in one loci.

Our preliminary observations (Rubáčová \& Melišková 2020) were not confirmed by subsequent molecular analyzes. However, molecular data revealed that the male M12059 bred for an extremely long time (a total of 185 days), he established five broods, raised 19 young, but he did not breed with only one, but with two females. Moreover, the male acquired a new mate during the incubation period of the third breeding attempt (see table 1 in Rubáčová \& Melišková 2020). One male breeding with multiple females was documented in other kingfisher populations several times (Čech 2007, 2009, 2017, Libois 2018). However, the relatively short distance (170 $\mathrm{m})$ between the two nesting burrows together with raising many offspring from both broods indicates that the possibility of simultaneous bigamy is relatively low. It is known that birds are unlikely to respect each other without any aggressive attacks leading to the interruption of breeding or the rearing of a lower number of young for a distance shorter than $200 \mathrm{~m}$ (Čech 2009). The distance between burrows of two females mating with the same male is usually several hundred meters to kilometers (Čech 2017, Libois 2018). Although there is evidence of one case of simultaneous bigamy, where the distance between burrows was 150 meters (Čech 2017), which does not completely rule out this possibility, but a partner exchange is more likely. Further, it is not clear whether the female really left, or the male lost his mate in some way (e.g. by predation). Naturally, there is evidence of occasions when a female leaving a male from the first breeding and finding a new partner for the second breeding (Čech 2006, 2009, 2017, Libois 2018). Even though, it appeared in the year with low population density, after the harsh winter in 2017, during which two-third of the kingfisher population disappeared (Rubáčová et al. 2021). It is similar to case of the Piping Plover (Charadrius melodus), where in normally monogamous pairs breeding once a year became double breeding with the mate exchange in years with small population densities (Hunt 
et al. 2015). Further, it is known for many bird species that the abandoned parent successfully raises the young (Winkler 1987), but often in fewer numbers than the parents would raise together. By this way, they reduce the probability of being abandoned (Houston \& Davies 1985, Witthingam et al. 1994, Rosmanith et al. 2009). After establishing another brood with a new partner, the kingfisher male raised six young from the full clutch of seven eggs from previous brood, which is common for kingfisher (Čech 2009, own unpublished data.), as the male is an efficient hunter of a large prey (Čech \& Čech 2017), for which it is not a problem to catch a sufficient number of fish and provide them to chicks (Vilches 2012, 2013). Finally, such behaviour indicates that leaving a partner is a minority strategy for kingfisher (Čech 2009, Libois 2018, own unpublished data). From this point of view, the male seems to have lost his mate rather than been abandoned.

\section{Acknowledgements}

Funding for this research in Slovakia was supplied by grant LIFE12 NAT/SK/001137, UK/162/2020. Permission to carry out the study was granted by Ministry of the Environment of the Slovak Republic.

\section{Súhrn}

Rybárik riečny patrí medzi málo druhov, ktoré hniezdia niekol'kokrát do roka, pričom často jednotlivé hniezdenia prekrývajú. Dížka prekrývania hniezdení sa pohybuje od 5 do 23 dní a počet úspešných znášok sa pohybuje od jednej do štyroch. V roku 2018 bol zdokumentovaný prípad hniezdneho páru, u ktorého sa na základe označenia jedincov a ich pozorovaním, ale už nie ich spätným odchytom predpokladalo, že hniezdil extrémne dlho a založil až pät' znášok za sezónu. Dve hniezdenia boli neúspešné a z d'alších troch úspešne vychovali 19 mlád'at. Ciel'om tejto práce bolo zistit', či u sledovaného hniezdneho páru nedošlo k mimo-párovým interakciám alebo $\mathrm{k}$ výmene partnera $\mathrm{v}$ priebehu dlhej hniezdnej sezóny, ktoré sme pozorovaním nezaznamenali. Molekulárne analýzy odhalili, že samec M12059 síce hniezdil extrémne dlho (spolu 185 dní), založil pät' znášok, v ktorých vychoval 19 mlád'at, avšak nehniezdil len $\mathrm{s}$ jednou samicou, ale s dvomi. Pomerne krátka vzdialenost' (170 m) medzi dvomi hniezdnymi norami spolu s vyvedením vysokého počtu mlád'at z oboch hniezdení znižuje pravdepodobnost', že by išlo o simultánnu bigamiu, pretože je známe, že ak rybáriky hniezdia menej než 200 m od seba, správajú sa vel'mi agresívne voči sebe navzájom, čo vyúst'uje do zníženého počtu vychovaného potomstva a často až do likvidácie znášok (Čech 2009). Preto predpokladáme, že došlo skôr k výmene partneriek a to konkrétne medzi tretím a štvrtým hniezdením, ktoré sa medzi sebou prekrývali 23 dní. Dížka prekryvu naznačuje, že samec musel novú partnerku nájst' ešte $v$ priebehu inkubácie (vid' tab. 1 v Rubáčová a Melišková 2020). Treba však dodat', že nedokážeme s istotou povedat', či došlo k opusteniu partnera a získaniu nového, alebo samec o partnerku nejakým spôsobom prišiel (napr. predáciou) a tak si našiel aj v priebehu náročnej hniezdnej fázy novú. Na základe štúdií ukazujúcich, že opustenie partnera je minoritnou stratégiou tohto druhu (Čech 2009, Libois 2018, naše nepublikované údaje), usudzujeme vyššiu pravdepodobnost' toho, že samec skôr o samicu prišiel, než že by ho bola opustila.

\section{References}

BÉziers P. \& Roulin A. 2016: Double brooding and offspring desertion in the Barn Owl (Tyto alba). Journal of Avian Biology 47: 235-44.

Cramp S. 1992: The Birds of the Western Palearctic, Vol. IV. - Oxford University Press, Oxford \& New York.

ČECH P. 2006: Breeding biology of the Kingfisher (Alcedo atthis) and the possibilities of its protection in the Czech Republic. - Sylvia 42: 50-65.

ČECH P. 2007: Charakteristika populace ledňáčka říčního (Alcedo atthis) hnízdící na území České republiky. Pp.: 12-22. In: ČECH P. (ed.): Ledňáček říční (Alcedo atthis), jeho ochrana a výzkum. Metodika ČSOP č. 34, 02/19. ZO ČSOP, Vlašim.

ČECH P. 2009: Contribution to understanding of breeding biology of the Eurasian Kingfisher. - Pp.: 38-51. In: ČECH P. (ed.): Sborník referátů z II. mezinárodního semináře Ledňáček říční (Alcedo atthis), jeho ochrana 
a výzkum. ZO ČSOP, Vlašim.

ČECH P. 2010: Length of the breeding season of the Eurasian Kingfisher (Alcedo atthis) in the Czech Republic. - Sylvia 46: 53-61.

ČCH P. 2017: Findings to the territoriality of the Common Kingfisher (Alcedo atthis) and their use in the fieldwork (when monitoring the nesting density and when studying the dynamics of its regional population) Pp.: 44-55. In: ČECH P. (ed.): Sborník referátů z III. mezinárodního semináře Ledňáček říční (Alcedo atthis) jeho ochrana a výzkum. ZO ČSOP, Vlašim.

ČECH M. \& С̆ECH P. 2017: Effect of brood size on food provisioning rate in Common Kingfishers Alcedo atthis. - Ardea 105: 5-17.

EMLEn S. T. \& ORING L. W. 1977: Ecology, sexual selection, and the evolution of mating systems. - Science 197: 215-223.

Griffith S. C., Owens I. P. F. \& Thuman K. A. 2002: Extra pair paternity in birds: a review of interspecific variation and adaptive function. - Molecular Ecology 11: 2195-212.

HAFtoRn S. 1978: Cooperation between the male and female Goldcrest Regulus regulus when rearing overlapping double broods. - Ornis Scandiaca 9: 124.

Houston A. I. \& Davies N. B. 1985: The evolution of cooperation and life history in the dunnock Prunella modularis. - Blackwell Scientific, Oxford.

Friedrich M. J., Bomberger Brown M., Jorgensen J. G., Catlin D. H. \& Fraser J. D. 2015: Density dependent double brooding in Piping Plovers (Charadrius melo$d u s)$ in the Northern Great Plains, USA. - Waterbirds 38: 321-329.

Jamieson S. E. 2011: Pacific Dunlin Calidris alpina pacifica show high propensity for second clutch production. - Journal of Ornithology 152: 1013-1021.

LACK D. 1968: Ecological adaptations for breeding in birds. - Methuen, London.

Libois R. 2018: Plumes d'azur. Histoire naturelle du martin-pêcheur d'Europe. - Presses Universitaires de Liége, Gembloux.

Morgan R. \& Glue D. 1977: Breeding, mortality and movements of Kingfishers. - Bird Study 24: 15-24.

NovotnÝ K. 1994: Four breeding attempts of Eurasian Kingfisher (Alcedo atthis) in one season. - Sylvia 30: 148-151.

Pogány Á., Szentirmai I., Komdeur J. \& Székely T.
2008: Sexual conflict and consistency of offspring desertion in Eurasian penduline tit Remiz pendulinus. - BMC Evolutionary Biology 8: 1-7.

Rossmanith E., Blaum N., Höntsch K. \& Jeltsch F. 2009: Sex-related parental care strategies in the lesser spotted woodpecker Picoides minor: of flexible mothers and dependable fathers. - Journal of Avian Biology 40: 28-33.

Rubáčová L., Čech P., MelišKová M. \& Balážová M. 2020: The length of breeding season in two populations of the Common Kingfisher (Alcedo atthis). Sylvia 56: 39-48.

RubáČová L. \& MelišKová M. 2020: Extreme breeding effort of Common Kingfisher (Alcedo atthis). Tichodroma 32: 43-46.

Rubáčová L., Čech P., MelišKová M., Čech M. \& ProcházKa P. 2021: The effect of age, sex and winter severity on return rates and apparent survival in the Common Kingfisher Alcedo atthis. - Ardea 109: $15-25$.

StęPNIEWSKi J. \& HaluPKa L. 2018: Overlapping breeding attempts in the Bearded Tit (Panurus biarmicus). Avian Research 9: 1-5.

TurČoková L., MelišKová M. \& Balážová M. 2016: Nest site location and breeding success of Common Kingfisher (Alcedo atthis) in the Danube River system. - Folia Oecologica 43: 74-82.

Vilches A., Miranda R. \& Arizaga J. 2012: Fish prey selection by the Common kingfisher Alcedo atthis in Northern Iberia. — Acta Ornithologica 47: 167-175.

Vilches A., Arizaga J., Miranda R. \& Ibbotson A. 2013: Impact of Common Kingfisher on a salmon population during the nestling period in southern England. - Knowledge and Management of Aquatic Ecosystems 410: 03.

Wallander J. \& Andersson M. 2003: Reproductive tactics of the Ringed Plover (Charadrius hiaticula). - Journal of Avian Biology 34: 259-266.

Warriner J. S., Warriner J. C., Page G. W. \& Stenzel L. E. 1986: Mating system and reproductive success of a small population of polygamous Snowy Plovers. — Wilson Bulletin 98: 15-37.

Westneat D. F. \& Stewart I. R. K. 2003: Extra-pair paternity in birds: causes, correlates, and conflict. - Annual Review of Ecology, Evolution and Systematics 34: 365-96. 
WiNKLER D. W. 1987: A general model for parental care. - American Naturalist 130: 526-543.

Whittingham L. A., Dunn P. O. \& Robertson R. J. 1994:

Female response to reduced male parental care in birds: an experiment in tree swallows. - Ethology
96(3): 260-269.

Woodall P. F. 2001: Family Alcedinidae (Kingfishers). Pp.: 130-244. In: del Hoyo J., Elliott A. \& SargaTAL J. (eds.): Handbook of the Birds of the World, Vol. 6, Mousebirds to Hornbills. Lynx Edicions, Barcelona.

Received: 17. 1. 2022

Accepted: 16. 2. 2022

Online: 21. 2. 2022 